DOT/FAA/AM-04/21

Office of Aerospace Medicine Washington, DC 20591

\section{A Longitudinal Study of Meyers-Briggs Personality Types in Air Traffic Controllers}

Carolyn S. Dollar

David J. Schroeder

Civil Aerospace Medical Institute

Federal Aviation Administration

Oklahoma City, OK 73125

December 2004

Final Report

This document is available to the public through:

-The Defense Technical Information Center Ft. Belvior, VA 22060

-The National Technical Information Service

Springfield, VA 22161

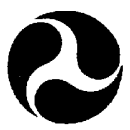

U.S. Department

of Transportation

Federal Aviation Administration 


\section{NOTICE}

This document is disseminated under the sponsorship of the U.S. Department of Transportation in the interest of information exchange. The United States Government assumes no liability for the contents thereof. 
Technical Report Documentation Page

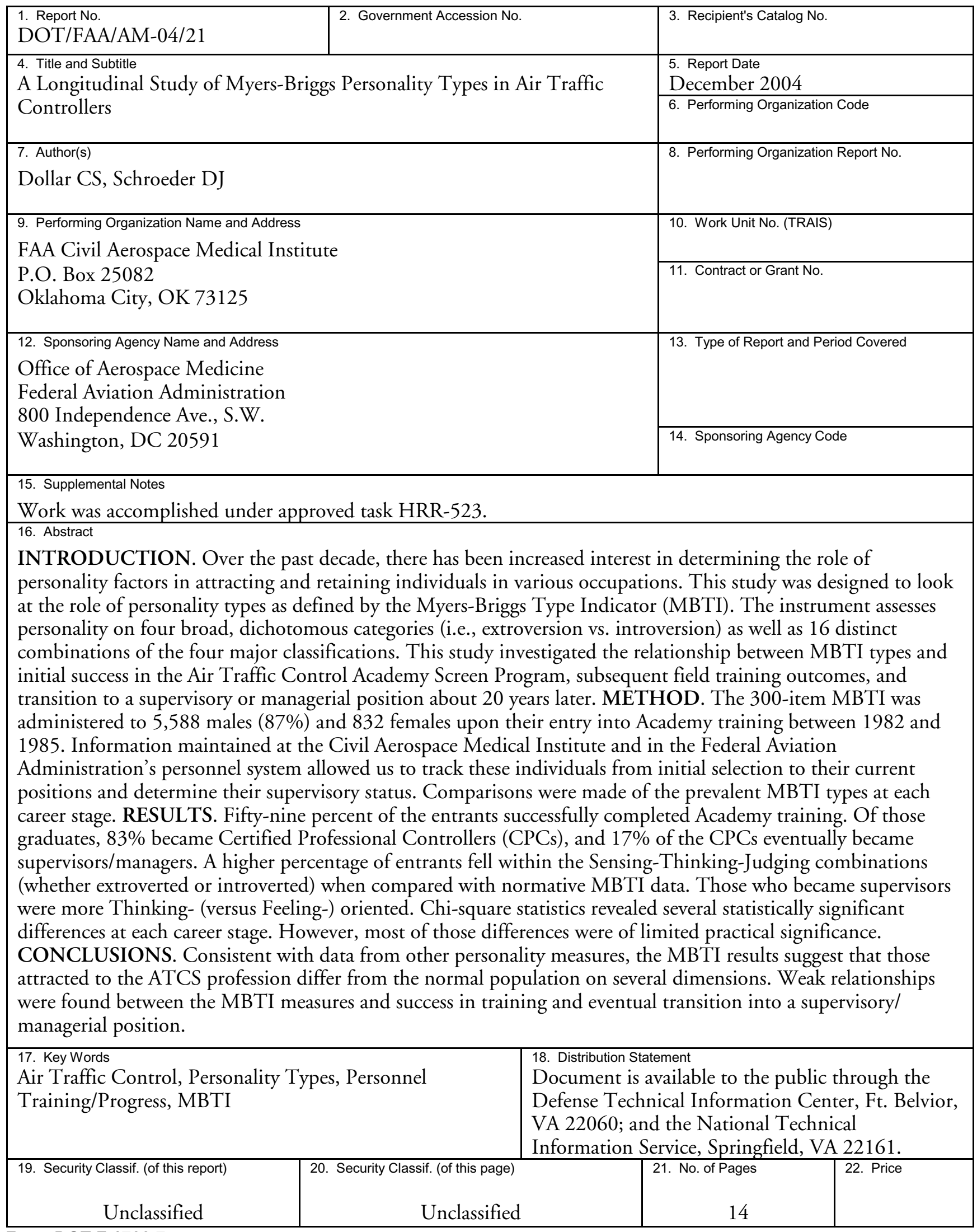

Form DOT F 1700.7 (8-72)

Reproduction of completed page authorized 



\section{A Longitudinal Study of Meyers-Briggs Personality Types in Air Traffic Controllers}

\section{INTRODUCTION}

Over the past two decades, there has been increased interest in determining the role of personality factors in attracting and retaining individuals in various occupations. One popular personality test is the Myers-Briggs Type Indicator (MBTI), a paper and pencil test based on Jungian theory (Jung, 1971) concerning personality preferences that involve: modes of orientation to the world (Extroversion/Introversion); ways of perceiving (Sensing/ Intuitive); how judgments are formed (Thinking/Feeling); and a fourth dimension, decision-making (Judging/ Perceptive). In his review of the MBTI, Devito (1985) indicates that it is "...probably the most widely used instrument for non-psychiatric populations in the areas of clinical, counseling, and personality assessment (pg. 1030)." More recently, Shuit (2003) indicates that, at the time of its $60^{\text {th }}$ birthday in October, the MBTI remains as the most popular and widely used personality-assessment tool of its kind in the world. While the Myers-Briggs Type Indicator (MBTI) is used in diverse areas ranging from education, career development, organizational behavior, group functioning, team development, and leadership (Shuit, 2003), one of the more common applications is to use it to demonstrate how individuals of different types approach their work and problem solving in a different manner. These differences have the potential to significantly influence group functioning and team development in the workplace.

The popularity of the MBTI exists despite concerns about the psychometric properties of the dimensions. Those concerns range from the factor structure of the scales, whether the dimensions are type versus continuous, the presence of dominant and auxiliary functions, and whether the scales fully measure the dimensions they intend to measure (Devito, 1985, Mendelsohn, 1965, Sundberg, 1965, and Stricker \& Ross, 1964). Quenk (2000) indicates that a number of these concerns have been addressed in the more recent revision (Form M - 1998) of the instrument.

Murray and Johnson (2001) used this instrument to identify the types of females who were more successful at the U.S. Naval Academy (USNA). Although the MBTI type classifications did not prove highly predictive of academic or military success, there was a trend for those who entered the USNA to be more extroverted.
Additionally, types of individuals who were more Sensing-Thinking-Judging were more likely to graduate than the other MBTI type groupings.

Westerman, Grandy, Combs, and Turner (1989) used the MBTI in an attempt to determine the interaction of personality type with academic performance for persons in their first year of dental school. They found only low and non-significant correlations between MBTI type and success as measured by grade point averages. In another study concerning the medical field, Stilwell, Wallick, Thal, and Burleson (2000) compared personality types of physicians from the 1950s with those of doctors 50 years later. They reported that type distribution overall has remained primarily consistent with a slight increase in Judging types. It is interesting to note that the percentage of types among females in the earlier group more closely resembled those of the males but became more representative of the general population in the Feeling dimension as time passed and medicine became less of a male-dominated profession.

In the Federal Aviation Administration (FAA), research has focused on the traits of personnel who desire to become Air Traffic Control Specialists (ATCSs) in addition to the more traditional emphasis on cognitive abilities. From the agency's standpoint, significant costs are associated with the recruitment, selection, and training of individuals for this profession both at the FAA Academy and in the field. As for those who enter training as an ATCS, a year to more than three years might be spent in pursuing this career before qualification is completed and the individual joins the ranks as a certified professional controller (CPC). Thus, in an attempt to reduce costs to both the government and the individual, we designed this study to look at the potential contribution of personality types as defined by the MBTI.

Based on the distribution of MBTI types within the US, as reported by Hammer and Mitchell (1996), we hypothesized that personality traits measured at various stages of a career in the ATCS occupation would differentiate between controllers who pass Academy or field training or who progress to supervisory levels from those who do not. A secondary interest was directed towards Schneider's (1987) emphasis on the role of attraction, selection, and attrition (ASA) in increasing similarity among members of a workforce. 


\section{METHOD}

\section{Sample/Procedure}

The MBTI (Form G) was administered to 5,588 males $(87 \%)$ and 832 females upon entry into the FAA ATCS Academy Screening program between 1982 and 1985. Information maintained at the Civil Aerospace Medical Institute and in the FAA's consolidated personnel system allowed us to track these individuals from initial selection to their current positions and determine their supervisory status. Correlations among the MBTI types and three stages of career progression were computed, and Chisquare comparisons were made of the prevalent MBTI types by gender and at each career stage.

\section{Measure}

The instrument is comprised of forced-choice, self-reported responses that are also dichotomous (i.e. "scheduled" vs. "unplanned") for 89 of the 94 items that are used in the final scoring for the four "types." Each item is included in only one of these major categories. A caveat to the reader regarding the results presented for the four major dimensions: The pairings (e.g. IntrovertedExtroverted) represent the two poles of the dichotomy. Thus, to avoid any misinterpretations, it is important to remember that, if we observe a larger percentage of one of the poles (Introverted) in comparison with another group, the opposing type will be reduced by the same percentage. As an example, if we observed a higher percentage of extroverts in the ATCSs entrants than in the normative group, there will be a correspondingly smaller percentage of introverts. Our discussion will generally focus on the pole of the dichotomy that represents the larger percentage of the ATCSs.

For further comparative purposes, 16 distinct combinations of the four major classifications were also calculated (i.e., Introverted-Sensing-Judging-Perceptive). For readability, we will refer to these 16 combinations by initials (e.g., ISJP), a complete listing of each along with a complete description of the personality dimensions are shown in the table provided by an article found on the Internet (2004) in Appendix A.

\section{RESULTS}

Fifty-nine percent of the entrants successfully completed Academy training. Of those graduates, $82.8 \%$ became Certified Professional Controllers (CPCs), and 18.8\% of the CPCs eventually became supervisors/managers. Table 1 shows comparisons across the ATCS career strata for the four major MBTI types. Included are adult population norms obtained from Hammer and Mitchell, 1996.

\section{Comparison of Adult MBTI Norms With All ATCSS Throughout Their Progression}

Initial comparisons show that the percents of entrants were significantly lower in the Sensing $\left(X^{2}=5.92, \mathrm{p}<.05\right)$ but higher in the Thinking $\left(X^{2}=440.59, \mathrm{p}<.001\right)$ and Judging $\left(X^{2}=67.28, \mathrm{p}<.001\right)$ categories than those of the normal population. Additionally the percentages of those

Table 1. Comparisons of ATCS Entrants With Population Norms and Career Status

\begin{tabular}{|c|c|c|c|c|c|c|c|c|}
\hline \multirow[b]{2}{*}{ PATTERN } & \multicolumn{8}{|c|}{ Percent in each pattern type } \\
\hline & $\begin{array}{c}\text { Total } \\
\text { Population } \\
\text { Norms } \\
\mathrm{N}=1267 \\
\end{array}$ & $\begin{array}{c}\text { Total } \\
\text { ATCS } \\
\text { Entrants } \\
\mathrm{N}=6420 \\
\end{array}$ & $\begin{array}{c}\text { Total } \\
\text { ATCS } \\
\text { Pass } \\
\mathrm{N}=3782 \\
\end{array}$ & $\begin{array}{c}\text { Total } \\
\text { ATCS } \\
\text { Not Pass } \\
\mathrm{N}=2637\end{array}$ & $\begin{array}{c}\text { Total } \\
\text { ATCS } \\
\text { CPCs } \\
\mathrm{N}=2873 \\
\end{array}$ & $\begin{array}{c}\text { Total } \\
\text { ATCS } \\
\text { Not CPCs } \\
\mathrm{N}=909 \\
\end{array}$ & $\begin{array}{c}\text { Total } \\
\text { ATCS } \\
\text { Sup/Man } \\
\mathrm{N}=539\end{array}$ & $\begin{array}{c}\text { Total } \\
\text { ATCS Not } \\
\text { Sup/Man } \\
\mathrm{N}=2334 \\
\end{array}$ \\
\hline EXTROVERT & 46.3 & 50.0 & 49.8 & 50.2 & 50.2 & 48.5 & 54.7 & 49.1 \\
\hline INTROVERT & 53.7 & 50.0 & 50.2 & 49.8 & 49.8 & 51.5 & 45.3 & 51.9 \\
\hline SENSING & 68.1 & 64.5 & 64.5 & 64.5 & 66.1 & 59.7 & 67.2 & 65.8 \\
\hline $\begin{array}{l}\text { INTUITIVE } \\
(\mathrm{N})\end{array}$ & 31.9 & 35.5 & 35.5 & 35.5 & 33.9 & 40.3 & 32.8 & 34.2 \\
\hline THINKING & 52.9 & 81.5 & 82.4 & 80.2 & 82.4 & 82.7 & 86.8 & 81.3 \\
\hline FEELING & 47.1 & 18.5 & 17.6 & 19.8 & 17.6 & 17.3 & 13.2 & 18.6 \\
\hline JUDGING & 58.1 & 69.9 & 68.5 & 71.8 & 68.0 & 70.2 & 71.4 & 67.2 \\
\hline PERCEPTIVE & 41.9 & 30.1 & 31.5 & 28.2 & 32.0 & 29.8 & 28.6 & 32.8 \\
\hline
\end{tabular}


who passed the Academy Screen were considerably higher than those of failures in the Thinking type $\left(X^{2}=5.29, \mathrm{p}\right.$ $<.05)$. Within the Sensing group, the percent of ATCSs who eventually became CPCs was greater $\left(X^{2}=12.08\right.$, $\mathrm{p}<.01)$ than that the failure percentages of those who failed field training. Finally, there were significantly more Extroverted $\left(X^{2}=5.47, \mathrm{p}<.05\right)$, Judging $\left(X^{2}=3.63, \mathrm{p}<\right.$ $.05)$ and Thinking $\left(X^{2}=9.01, \mathrm{p}<.01\right)$ types who achieved supervisory or higher status in their careers than nonsupervisors.

\section{Comparison of Adult MBTI Norms With Male ATCSs Throughout Their Progression}

Table 2 shows the comparisons for the same subgroups in each of the four major MBTI dichotomies for males. Within these groupings, the only significant difference in the EI category was the larger percentage of Extroverted supervisors/managers, compared with non-supervisors $\left(X^{2}=4.33, \mathrm{p}<.05\right)$. For the $\mathrm{SN}$ breakout, the proportion of those who were successful in field training was significantly more Sensing $\left(X^{2}=10.12, \mathrm{p}<.001\right)$ than of males who were not. When TF $\left(X^{2}=71.56, \mathrm{p}<.001\right)$ and $\mathrm{JP}\left(X^{2}=61.71, \mathrm{p}<.001\right)$ types were compared, significant differences were found between the percentages of both Academy entrants and the population norms, as well as the group that passed Academy training (TF $X^{2}=5.9, \mathrm{p}<$ $.01)$, (JP $\left.X^{2}=5.3, \mathrm{p}<.05\right)$ versus those who either failed or withdrew. Additionally, the percentage of Extroverts $\left(X^{2}=4.33, \mathrm{p}<.05\right)$ and Thinkers $\left(X^{2}=5.55, \mathrm{p}<.01\right)$, as well as the more Judgmental $\left(X^{2}=3.01, \mathrm{p}<.05\right)$ in the group who progressed to supervisory/managerial positions, was significantly higher than the group of non-supervisors.

\section{Comparison of Adult MBTI Norms With Female ATCSs Throughout Their Progression}

When comparisons for female groupings were examined (see Table 3), significantly higher percentages of Extroverts $\left(X^{2} 11.32, \mathrm{p}<.01\right)$ and Thinkers $\left(X^{2}=181.43\right.$, $\mathrm{p}$ $<.001)$ and lower percentages of Sensing types $\left(X^{2}=16.07\right.$, $\mathrm{p}<.01)$ were found for entrants versus the population norm. The only significant difference among female comparisons concerning failure/passing of Academy training was the higher percentage of Judging types $\left(X^{2}=2.97\right.$, p $<.05)$ in the group that failed. Where CPC status was concerned, the female group that continued past field training contained significantly more Extroverts $\left(X^{2}=5.91\right.$, $\mathrm{p}<.01)$ than that comprised of failures after passing the Academy. In addition, the female ATCS supervisors and managers group is comprised of a larger percentage of Thinking $\left(X^{2}=614, \mathrm{p}<.01\right)$ versus Feeling types.

\section{Comparisons of Male and Female Entrants/ATCSs}

Although the percentages are not shown, Table 4 shows a summary of all above-mentioned comparisons. In addition, significant differences between gender within the MBTI types by career strata are described. Examination of the EI differences revealed that the percentages of female extroverts were higher than males for entrants $\left(X^{2}=13.40\right.$, $p$ $<.01)$, those who passed the Academy training $\left(X^{2}=7.01\right.$, $\mathrm{p}<.05)$ and those who became CPCs $\left(X^{2}=11.91, \mathrm{p}<\right.$

Table 2. Comparisons of Male ATCS Entrants With Population Norms and Career Status

\begin{tabular}{|c|c|c|c|c|c|c|c|c|}
\hline \multirow[b]{2}{*}{ PATTERN } & \multicolumn{8}{|c|}{$\underline{\text { Percent in each pattern type }}$} \\
\hline & $\begin{array}{c}\text { Population } \\
\text { Male } \\
\text { Norms } \\
\mathrm{N}=599 \\
\end{array}$ & $\begin{array}{c}\text { ATCS } \\
\text { Male } \\
\text { Entrants } \\
\mathrm{N}=5588 \\
\end{array}$ & $\begin{array}{c}\text { ATCS } \\
\text { Male } \\
\text { Passers } \\
\mathrm{N}=3283 \\
\end{array}$ & $\begin{array}{c}\text { ATCS } \\
\text { Males } \\
\text { Not Pass } \\
\mathrm{N}=2305 \\
\end{array}$ & $\begin{array}{c}\text { ATCS } \\
\text { Male } \\
\text { CPCs } \\
\mathrm{N}=2521 \\
\end{array}$ & $\begin{array}{c}\text { ATCS } \\
\text { Males } \\
\text { Not CPCs } \\
\mathrm{N}=762 \\
\end{array}$ & $\begin{array}{c}\text { ATCS } \\
\text { Male } \\
\text { Sup/Man } \\
\text { N=457 }\end{array}$ & $\begin{array}{c}\text { ATCS } \\
\text { Males Not } \\
\text { Sup/Man } \\
\mathrm{N}=2064 \\
\end{array}$ \\
\hline EXTROVERT & 45.4 & 49.1 & 48.9 & 49.3 & 49.0 & 48.8 & 53.4 & 48.0 \\
\hline INTROVERT & 54.6 & 50.9 & 51.1 & 50.7 & 51.0 & 51.2 & 46.6 & 52.0 \\
\hline SENSING & 64.4 & 65.0 & 65.3 & 64.6 & 66.8 & 60.5 & 68.5 & 66.4 \\
\hline $\begin{array}{l}\text { INTUITIVE } \\
(\mathrm{N})\end{array}$ & 35.6 & 35.0 & 34.7 & 35.4 & 33.2 & 39.5 & 31.5 & 33.6 \\
\hline THINKING & 68.6 & 82.8 & 83.8 & 81.3 & 83.6 & 84.4 & 87.3 & 82.8 \\
\hline FEELING & 31.4 & 17.2 & 16.2 & 18.7 & 16.4 & 15.6 & 12.7 & 17.2 \\
\hline JUDGING & 55.1 & 70.7 & 69.5 & 72.4 & 69.0 & 71.3 & 72.4 & 68.2 \\
\hline PERCEPTIVE & 44.9 & 29.3 & 30.5 & 27.6 & 31.0 & 28.7 & 27.6 & 31.8 \\
\hline
\end{tabular}


Table 3. Comparisons of Female ATCS Entrants With Population Norms and Career Status

\begin{tabular}{|c|c|c|c|c|c|c|c|c|}
\hline \multirow[b]{2}{*}{ PATTERN } & \multicolumn{8}{|c|}{$\underline{\text { Percent in each pattern type }}$} \\
\hline & $\begin{array}{c}\text { Population } \\
\text { Female } \\
\text { Norms } \\
\mathrm{N}=668\end{array}$ & $\begin{array}{c}\text { ATCS } \\
\text { Female } \\
\text { Entrants } \\
\mathrm{N}=832\end{array}$ & $\begin{array}{c}\text { ATCS } \\
\text { Female } \\
\text { Passers } \\
\mathrm{N}=499\end{array}$ & $\begin{array}{c}\text { ATCS } \\
\text { Females } \\
\text { Not Pass } \\
\mathrm{N}=332\end{array}$ & $\begin{array}{c}\text { ATCS } \\
\text { Female } \\
\text { CPCs } \\
\mathrm{N}=352\end{array}$ & $\begin{array}{c}\text { ATCS } \\
\text { Females } \\
\text { Not CPCs } \\
\mathrm{N}=147\end{array}$ & $\begin{array}{c}\text { ATCS } \\
\text { Female } \\
\text { Sup/Man } \\
\mathrm{N}=82\end{array}$ & $\begin{array}{c}\text { ATCS } \\
\text { Females } \\
\text { Not } \\
\text { Sup/Man } \\
\text { N=270 }\end{array}$ \\
\hline EXTROVERT & 47.2 & 55.9 & 55.3 & 56.9 & 58.8 & 46.9 & 62.2 & 57.8 \\
\hline INTROVERT & 52.8 & 44.1 & 44.7 & 43.1 & 41.2 & 53.1 & 37.8 & 42.2 \\
\hline SENSING & 71.4 & 61.5 & 59.5 & 64.5 & 61.1 & 55.8 & 59.8 & 61.5 \\
\hline $\begin{array}{l}\text { INTUITIVE } \\
(\mathrm{N})\end{array}$ & 28.6 & 38.5 & 40.5 & 35.5 & 38.9 & 44.2 & 40.2 & 38.5 \\
\hline THINKING & 38.8 & 73.2 & 73.7 & 72.6 & 73.6 & 74.1 & 84.1 & 70.4 \\
\hline FEELING & 61.2 & 26.7 & 26.3 & 27.4 & 26.4 & 25.9 & 15.9 & 29.6 \\
\hline JUDGING & 60.8 & 64.3 & 61.9 & 67.8 & 60.8 & 64.6 & 65.9 & 59.3 \\
\hline PERCEPTIVE & 39.2 & 35.7 & 38.1 & 32.2 & 39.2 & 35.4 & 34.1 & 40.7 \\
\hline
\end{tabular}

$.01)$. The male groupings had higher percentages for most of the remaining MBTI type comparisons. Specifically, they were represented by a statistically larger number of Sensing types than their female counterparts, when both passing Academy training and making CPC were concerned. Males also had higher percentages than females on both Thinking and Judging characteristics whether the entrant, Academy success, or CPC status groups were compared. However, (not shown) the percentages of ATCS females in the Thinking group were much closer to the ATCS males than with the population norms where the percentage of the TF dichotomy is reversed (over $2 / 3$ of the males were Thinking and almost $2 / 3$ of the females were Feeling types). Despite these differences, when the different combinations of types are considered together, the overall profile for males and females are similar (see later discussion regarding Fig. 1).

A more precise look at MBTI types was revealed when all combinations (16) of the four broad groups were analyzed (see Table 5). A higher percentage of entrants fell within the Sensing-Thinking-Judging combinations (whether Extroverted or Introverted) when compared with normative MBTI data. As indicated in Appendix A, persons with a combination of those 3 types are practical, matter-of-fact realists who like to be organized and run activities smoothly, regardless of distractions. All of the above traits would seem to be helpful for a controller who must remain attentive to visual and auditory information, quickly process that information, and then take action.

Figure 1 graphically depicts the 16 subtypes for males and females who entered the Academy Screen program. Table 5, along with Figure 1, are highly representative of the pattern of type combinations, no matter which gender, type of training, supervisory level, or other aspects of the career progression were analyzed. The most noticeable difference between the genders, as shown on the graph, are the higher percentages of males in the ESTJ and ISTJ subtypes.

Table 6 shows correlations for the career strata variables of our ATCS sample with the four major MBTI types. As shown, only the Judging/Perceiving category seemed to have any relationship with whether or not an individual passed or failed the Academy. However, this category showed an even stronger relationship with further progression in field training and eventual success in achieving CPC status. Yet, despite the significance, the relationship explains only a very small portion of the variance in predicting either success in the Academy or in achieving CPC status. Despite the large number of judging individuals who achieved success, the percentage within this type category was reduced from entry through CPC status. Sensing/Intuitive also played a role in predicting $\mathrm{CPC}$ status. A slightly higher percentage of Sensing types achieved CPC status. Finally, only the Thinking/Feeling type category showed a significant association with Supervisory or Managerial status during the career progression of an ATCS. A higher percentage of supervisors were Thinking types than in the CPC population. Given the overall diversity of types successful at each stage in their careers, the significant results found with respect to the correlations and other analyses do not reflect a sufficiently strong and consistent pattern to assist in the initial screening and selection process. 
Table 4. Comparisons of the four MBTI dichotomies by gender and career stratification

\begin{tabular}{|c|c|c|c|c|}
\hline$\underline{\text { COMPARISON }}$ & Extroverted or Introverted & 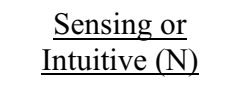 & $\frac{\text { Thinking or }}{\text { Feeling }}$ & Judging or Perceptive \\
\hline \multicolumn{5}{|c|}{ MALE PERCENTAGES } \\
\hline $\begin{array}{l}\text { ATCS Entrants vs. } \\
\text { Population Norms }\end{array}$ & $\begin{array}{l}49.1 \text { vs. } 45.4 \\
\text { NS }\end{array}$ & $\begin{array}{l}65.0 \text { vs. } 64.4 \\
\text { NS }\end{array}$ & $\begin{array}{l}\quad 82.8 \text { vs. } 68.6 \\
\text { Entrants more Thinking** }\end{array}$ & $\begin{array}{c}70.7 \text { vs. } 55.1 \\
\underline{\text { Entrants }} \text { more Judging } \\
* *\end{array}$ \\
\hline $\begin{array}{l}\text { a Pass vs. Not Pass } \\
\text { Academy }\end{array}$ & $\begin{array}{l}48.9 \text { vs. } 49.3 \\
\text { NS }\end{array}$ & $\begin{array}{l}65.3 \text { vs. } 64.6 \\
\text { NS }\end{array}$ & $\begin{array}{l}\quad 83.8 \text { vs. } 81.3 \\
\text { Passers more Thinking** }\end{array}$ & $\begin{array}{c}\begin{array}{c}69.5 \text { vs. } 72.4 \\
\text { Non-passers more }\end{array} \\
\text { Judging* }\end{array}$ \\
\hline $\begin{array}{l}\text { Certified Professional } \\
\text { Controllers (CPCs) vs. } \\
\text { Non-CPCs }\end{array}$ & $\begin{array}{c}49.0 \text { vs. } 48.8 \\
\text { NS }\end{array}$ & $\begin{array}{l}66.8 \text { vs. } 60.5 \\
\text { CPCs more } \\
\underline{\text { Sensing }}{ }^{* *}\end{array}$ & $\begin{array}{c}83.6 \text { vs. } 84.4 \\
\text { NS }\end{array}$ & $\begin{array}{c}69.0 \text { vs. } 71.3 \\
\text { NS }\end{array}$ \\
\hline $\begin{array}{l}\text { CPC Supervisor/ } \\
\text { Manager vs. Non- } \\
\text { supervisor/Manager }\end{array}$ & $\begin{array}{c}53.4 \text { vs. } 48.0 \\
\text { Supervisor/Manager } \\
\underline{\text { more Extroverted }}^{*}\end{array}$ & $\begin{array}{c}68.5 \text { vs. } 66.4 \\
\text { NS }\end{array}$ & $\begin{array}{c}87.3 \text { vs. } 82.8 \\
\text { Supervisor/Manager } \\
\underline{\text { more Thinking* }}\end{array}$ & $\begin{array}{c}72.4 \text { vs. } 68.2 \\
\text { Supervisor/Manager } \\
\text { more Judging* }\end{array}$ \\
\hline \multicolumn{5}{|c|}{ FEMALE PERCENTAGES } \\
\hline $\begin{array}{l}\text { ATCS Entrants vs. } \\
\text { Population Norms }\end{array}$ & $\begin{array}{l}55.9 \text { vs. } 47.2 \\
\text { Entrants more } \\
\text { Extroverted }^{* *}\end{array}$ & $\begin{array}{l}61.5 \text { vs. } 71.4 \\
\text { Population more } \\
\text { Sensing } * *\end{array}$ & $\begin{array}{l}73.2 \text { vs. } 38.8 \\
\text { Entrants more } \\
\text { Thinking** }\end{array}$ & $\begin{array}{l}64.3 \text { vs. } 60.8 \\
\text { NS }\end{array}$ \\
\hline $\begin{array}{l}{ }^{a} \text { Pass vs. Not Pass } \\
\text { Academy }\end{array}$ & $\begin{array}{l}55.3 \text { vs. } 56.9 \\
\text { NS }\end{array}$ & $\begin{array}{c}59.5 \text { vs. } 64.5 \\
\text { NS }\end{array}$ & $\begin{array}{c}73.7 \text { vs. } 72.6 \\
\text { NS }\end{array}$ & $\begin{array}{c}61.9 \text { vs. } 67.8 \\
\text { Non-passers more } \\
\text { Judging* }\end{array}$ \\
\hline $\begin{array}{l}\text { Certified Professional } \\
\text { Controllers (CPCs) vs. } \\
\text { Non-CPCs }\end{array}$ & $\begin{array}{c}58.8 \text { vs. } 46.9 \\
\text { CPCs more Extroverted* }\end{array}$ & $\begin{array}{l}61.1 \text { vs. } 55.8 \\
\text { NS }\end{array}$ & $\begin{array}{c}73.6 \text { vs. } 74.1 \\
\text { NS }\end{array}$ & $\begin{array}{c}60.8 \text { vs. } 64.6 \\
\text { NS }\end{array}$ \\
\hline $\begin{array}{l}\text { CPC Supervisor/ } \\
\text { Manager vs. Non- } \\
\text { supervisor/Manager }\end{array}$ & $\begin{array}{l}62.2 \text { vs. } 57.8 \\
\text { NS }\end{array}$ & $\begin{array}{l}59.8 \text { vs. } 61.5 \\
\text { NS }\end{array}$ & $\begin{array}{c}84.1 \text { vs. } 70.4 \\
\text { Supervisor/Manager } \\
\underline{\text { more Thinking* }}\end{array}$ & $\begin{array}{l}65.9 \text { vs. } 59.3 \\
\text { NS }\end{array}$ \\
\hline \multicolumn{5}{|c|}{ MALE VS FEMALE PERCENTAGES } \\
\hline${ }^{\mathrm{b}}$ ATCS Entrants & $\begin{array}{l}49.1 \text { VS } 55.9 \\
\text { Females more } \\
\underline{\text { Extroverted }}^{*}\end{array}$ & $\begin{array}{l}65.0 \text { vs. } 61.5 \\
\text { NS }\end{array}$ & $\begin{array}{l}82.8 \text { vs. } 73.2 \\
\text { Males more } \\
\text { Thinking** }\end{array}$ & $\begin{array}{l}70.7 \text { vs. } 64.3 \\
\text { Males more } \\
\text { Judging }\end{array}$ \\
\hline $\begin{array}{l}\text { a,b ATCS Who Passed } \\
\text { Academy }\end{array}$ & $\begin{array}{l}48.9 \text { vs. } 55.3 \\
\text { Females more } \\
\underline{\text { Extroverted }}^{* *}\end{array}$ & $\begin{array}{l}65.3 \text { vs. } 59.5 \\
\frac{\text { Males more }}{\underline{\text { Sensing* }}}\end{array}$ & $\begin{array}{l}83.8 \text { vs. } 73.7 \\
\text { Males more } \\
\underline{\text { Thinking }}{ }^{* *}\end{array}$ & $\begin{array}{l}69.5 \text { vs. } 61.9 \\
\text { Males more } \\
\underline{\text { Judging }}{ }^{* *}\end{array}$ \\
\hline $\begin{array}{l}{ }^{\mathrm{b}} \text { Passers Who Made } \\
\text { Certified Professional } \\
\text { Controller (CPC) }\end{array}$ & $\begin{array}{l}49.0 \text { vs. } 58.8 \\
\text { Females more } \\
\underline{\text { Extroverted }}^{* *}\end{array}$ & $\begin{array}{l}66.8 \text { vs. } 61.1 \\
\frac{\text { Males more }}{\underline{\text { Sensing* }}}\end{array}$ & $\begin{array}{l}83.6 \text { vs. } 73.6 \\
\text { Males more } \\
\text { Thinking** }\end{array}$ & $\begin{array}{l}69.0 \text { vs. } 60.8 \\
\text { Males more } \\
\underline{\text { Judging }}{ }^{* *}\end{array}$ \\
\hline $\begin{array}{l}\text { CPCs Who Made } \\
\text { Supervisor/Manager }\end{array}$ & $\begin{array}{c}53.4 \text { vs. } 62.2 \\
\text { NS }\end{array}$ & $\begin{array}{c}68.5 \text { vs. } 59.8 \\
\text { NS }\end{array}$ & $\begin{array}{c}87.3 \text { vs. } 84.1 \\
\text { NS }\end{array}$ & $\begin{array}{c}72.4 \text { vs. } 65.9 \\
\text { NS }\end{array}$ \\
\hline
\end{tabular}

${ }^{a}$ Not Pass includes persons who withdrew or failed

${ }^{\mathrm{b}}$ Most differences were due to the overall proportionately higher number males in the total sample

NS=Not Significant at .05 or below

* Significant $p<.05$

** Significant $p<.01$ 
Table 5. Distributions of MBTI Patterns for Population Norms Versus ATCS Samples

\begin{tabular}{|c|c|c|c|c|}
\hline$\underline{\text { Pattern }}$ & $\begin{array}{c}\text { Normal } \\
\text { Males }\end{array}$ & $\begin{array}{l}\text { ATCS } \\
\text { Males } \\
\end{array}$ & $\begin{array}{l}\text { Normal } \\
\text { Females } \\
\end{array}$ & $\begin{array}{c}\text { ATCS } \\
\text { Females } \\
\end{array}$ \\
\hline ISTJ & 19.4 & 24.1 & 12.3 & 17.2 \\
\hline ISFJ & 6.3 & 3.9 & 16.2 & 4.8 \\
\hline INFJ & 2.0 & 1.5 & 3.1 & 2.0 \\
\hline INTJ & 2.0 & 6.9 & 3.1 & 5.8 \\
\hline ISTP & 8.7 & 5.2 & 4.3 & 4.8 \\
\hline ISFP & 2.3 & 1.2 & 6.4 & 2.2 \\
\hline INFP & 4.5 & 2.1 & 4.2 & 2.6 \\
\hline INTP & 6.5 & 6.0 & 4.0 & 4.7 \\
\hline ESTP & 6.2 & 4.5 & 3.6 & 5.9 \\
\hline ESFP & 4.0 & 1.3 & 7.2 & 3.2 \\
\hline ENFP & 6.0 & 2.6 & 6.6 & 4.3 \\
\hline ENTP & 6.7 & 6.4 & 2.8 & 7.9 \\
\hline ESTJ & 12.9 & 21.9 & 7.3 & 18.6 \\
\hline ESFJ & 4.7 & 2.9 & 14.1 & 4.8 \\
\hline ENFJ & 1.5 & 1.7 & 3.4 & 2.6 \\
\hline ENTJ & 3.5 & 7.8 & 2.1 & 8.4 \\
\hline
\end{tabular}

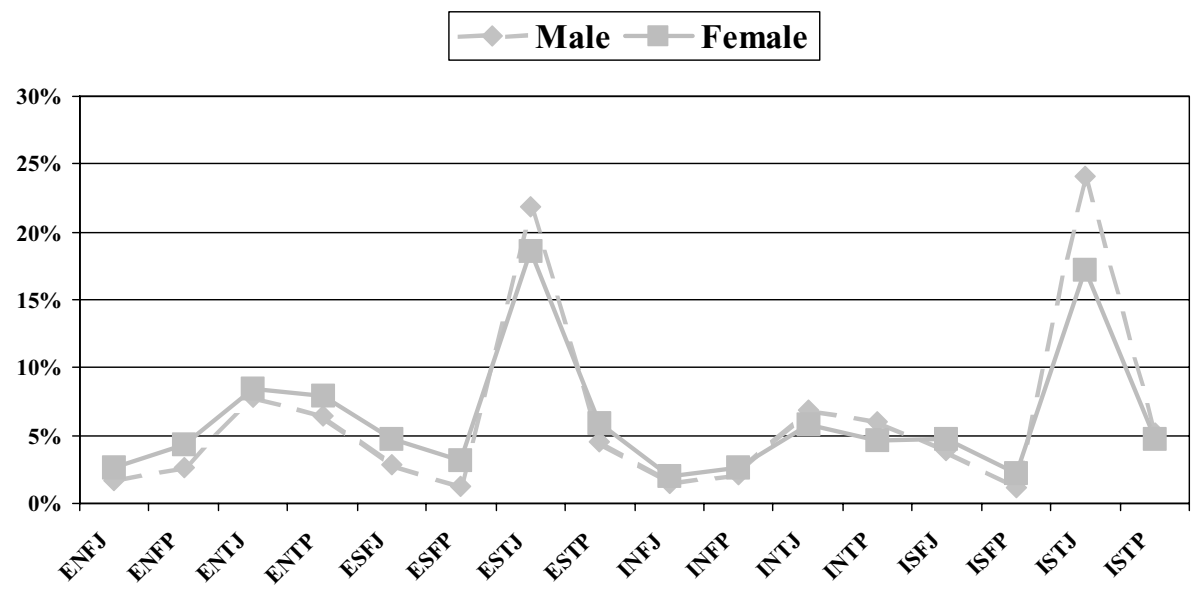

Figure 1. Myers-Briggs Type Indicator Scale Scores For Male Versus Females Who Entered the ATCS Academy Screen *

${ }^{*}$ Chi-Square test significant $<.01$

Table 6. Correlations of MBTI Variables With Passing Academy, Achieving CPC Status and Supervisory Level for Total Sample

\begin{tabular}{lclc}
\hline \multicolumn{1}{c}{$\begin{array}{c}\text { MBTI } \\
\text { Category }\end{array}$} & $\begin{array}{c}\text { Pass/Fail } \\
\text { Academy }\end{array}$ & $\begin{array}{c}\text { CPC } \\
\text { Status }\end{array}$ & $\begin{array}{c}\text { Supervisory } \\
\text { Level }\end{array}$ \\
\cline { 2 - 3 } Extroversion/Introversion & & & $\underline{-.005}$ \\
Sensing/Intuitive (N) & .000 & -.016 & -.044 \\
Thinking/Feeling & -.023 & $-.036^{*}$ & -.011 \\
Judging/Perceptive & $.035^{*}$ & -.010 & $-.068^{* *}$ \\
* Significant $\mathrm{p}<.05$ & & $.040^{* *}$ & -.036 \\
$* *$ Significant $\mathrm{p}<.01$ & & & \\
\end{tabular}




\section{CONCLUSIONS/DISCUSSION}

As in the Murray and Johnson (2001) study, the MBTI classifications were not highly predictive of success in either the Academy or in field training. While the SensingThinking-Judging types were the more common groups upon entry, graduation, and at the conclusion of field training, analyses suggest that a slightly smaller percentage of the Judging types were successful in the academy. Additionally, there was a trend for females in that study and the current one to be more extroverted.

Although the correlations obtained in this study demonstrated a greater ability of the MBTI to predict success in training than those obtained in the Westerman, Grandy, Combs, and Turner (1989) study concerning type with first-year GPA, they explained only a small amount of the overall variance and presented no clear-cut pattern throughout the entire career progression of an ATCS. Finally when we compared our results with the Stilwell, et al. (2000) personality types of another maledominated field, we found our ATCS gender comparisons to be relatively similar, as was true in their sample of 50 years earlier.

When compared with the population norms, there are indications that individuals attracted to the air traffic profession differ from those of the population norms. On the basis of the 16 distinct type patterns, there is a much higher percentage of STJs (both introverted and extroverted) in the group of ATCS entrants. This remains as the dominant pattern through the Academy program and into the field and even into the supervisory ranks. One of the more noticeable gender differences in this respect is the high percentage of Thinking female types (73.2\%) compared with $38.8 \%$ in the overall population. One consequence of this difference is that the percentages of males and females who comprise the 16 separate MBTI type groups appear to be more similar for controllers than for the general population.

These results lend some support to Schneider's theory (1957) that certain types of individuals are attracted to certain occupations. However, there is little evidence in these data that the diversity in MBTI types shifts significantly from entry through completion of field training. Even at the supervisory level, where there are indications that extroverts and thinking types are slightly more successful, the frequencies of the various types remain relatively close to that noted in the ATCS workforce. Of course, this observation does not take into account possible shifts in personal preferences from entry level to the present.

One area in which the results from our assessment of type in air traffic controllers may have direct implications for the workplace is that the information can be used to facilitate our understanding of how differences in the ways we view and interact with the world can influence how supervisors react and how individuals interact as members of work teams. In an article in Fortune magazine, Moore (1987) indicated that personality tests have regained prominence in the workplace, with a special emphasis on team building and management development. As we indicated earlier, a significant portion of the annual administrations of the MBTI involve aspects of organizational behavior; team building, management development, decision-making, conflict management, and leadership. This emphasis is also readily apparent if one conducts a search of the MBTI on the Internet. One factor that contributes to this interest is the ease with which the types can be translated into differences in perceiving and responding to events in the workplace.

For example, the MBTI views thinkers as responding to situations in a more impersonal way, preferring to use logic as they analyze facts. Judgers prefer to organize their world and stick to schedules and routines. On the other hand, individuals who are perceptive types prefer to keep their options open, remaining more jovial and carefree and are sometimes prone to analysis paralysis. When working in teams, a benefit of having a heterogeneous group comprised of different types is that the members bring different ways of viewing and analyzing a problem to the table. As a group member, the extroverted ESTJ may feel strongly that the situation calls for a logical analysis of the available data and a quick decision. In contrast, the INFP is more concerned about relationships with the group and tends to rely more on his or her intuitions, preferring to thoroughly review all options rather than make a quick decision. It is easy to see how these different approaches can present difficulties for the team leader, especially if his or her approach differs markedly from the other group members. Despite the appeal of these ideas, Gardner (1996) indicates that the literature to support the value of using the MBTI to facilitate teamwork and leadership behavior is relatively weak. However, the concepts do point to an important factor involving group processes, that individuals have a number or different styles in approaching their work and interacting with others, and that those differences can be used to improve understanding and communication. Supervisors and managers need to understand those differences and how they can be used to enhance organizational and team performance.

These data are consistent with ATCSs research using the $16 \mathrm{PF}$ in demonstrating that those attracted to the ATCS profession differ from the normal population on several dimensions. Schroeder and Dollar (1997) found that controllers were brighter than the average adult; less anxious and tense. Collins, Schroder, and Nye (1991) 
also found that entrants, as well as those who successfully completed the Academy program, reported lower levels of state and trait anxiety. Those findings, along with our results that academy entrants most commonly reveal Sensing-Thinking-Judging combinations, provide consistent evidence of some self-selection in who is attracted to the profession. However, the results also indicate that considerable diversity remains within the air traffic profession. Of the personality measures considered to date, anxiety appears to be the dimension that is most closely linked with success in training. These results offer only limited support for the relevance of MBTI dimensions on success in training and eventual transition to supervisor/manager. While a small consistent increase in predictability can reduce costs associated with the selection and training of personnel, consideration needs to turn to other measures, given the limited usefulness of the MBTI.

More research is needed to find a measure that would be more consistently predictive, thus saving both the individuals involved and the FAA a great deal of time and money.

\section{REFERENCES}

Collins, W.E., Schroeder, D. J, \& Nye, L.G. (1991). Relationship of anxiety scores to Academy and field training performance of Air Traffic Control Specialists. Aviation, Space, and Environmental Medicine, 62, 236-40.

Devito, A.J. (1985). Review of the Myers-Briggs Type Indicator. In O.K. Buros (Ed.), The Eighth Mental Measurements Yearbook (pp. 1030-2). Highland Park, NJ: The Gryphon Press.

Gardner, W.L. (1996). Using the Myers-Briggs Type Indicator to study managers: a literature review and research agenda. Journal of Management, 22 (1), 45-83.

Hammer, A.L. \& Mitchell, W.D. (1996). The distribution of MBTI types in the US by gender and ethnic group. Journal of Psychological Type, 37, 2 - 14.

Jung, C.G. (1971). The Collected Works of C.G. Jung; Vol 6. Psychological types (pp 510-555), Princeton, NJ: Princeton University Press. (Original work published in 1923).

Mendelsohn, G.A. (1965). Review of the Myers-Briggs Type Indicator. In O.K. Buros (ed.), The Sixth Mental Measurements Yearbook (pp. 321-2). Highland Park, NJ: The Gryphon Press.
Moore, T. (1987). Personality tests are back. Fortune, March 30: 74-78.

Murray, K.M. \& Johnson, W.B. (2001). Personality type and success among female naval academy midshipmen. Military Medicine, 166(10) 889-93.

Quenk, N.L. (2000) Essentials of Myers-Briggs Type Indicator assessment. New York: Wiley.

Schroeder, D.J. \& Dollar, C.S. (1997). Personality characteristics of pre-/post-strike air traffic control applicants. (DOT/FAA/AM-97/17), Washington, DC, Federal Aviation Administration Office of Aviation Medicine. ${ }^{1}$

Schneider, B. (1987). The people make the place. Personnel Psychology, 40, 437-53.

Shuit, D.P. (2003). At 60, Myers-Briggs is still sorting out and identifying people's types. Workforce Management (December), pp. 72-4.

Stilwell, N.A., Wallick, M.M., Thal, S.E., \& Burleson, J.A. (2000). Myers-Briggs type and medical specialty choice: A new look at an old question. Teaching and Learning in Medicine, 12(1), 14-20.

Stricker, L.J., and Ross, J. (1964). An assessment of some structural properties of the Jungian Personality inventory. Psychological Reports, 14, 623-43.

Sundberg, N.D. (1965). Review of the Myers-Briggs Type Indicator. In O.K. Buros (ed.), The Sixth Mental Measurements Yearbook (pp. 322-5). Highland Park, NJ: The Gryphon Press.

Westerman, G.H., Grandy, T.G., Combs, C.G., \& Turner, C.H. (1989). Personality variables as predictors of performance for first-year dental students. Journal of Dental Education, 53(4), 233-7.

Working out your Myers-Briggs Type. Retrieved April 10, 2004, from http://www.teamtechnology.co.uk/tt/tarticl/mb-simpl.htm

${ }^{1}$ This publication and all Office of Aerospace Medicine technical reports are available in full-text from the Civil Aerospace Medical Institute's Web site: http://www.cami.jccbi.gov/aam-400A/index.html 
APPENDIX A

CHARACTERISTICS OF THE COMBINATIONS OF ALL FOUR TYPE PREFERENCES 


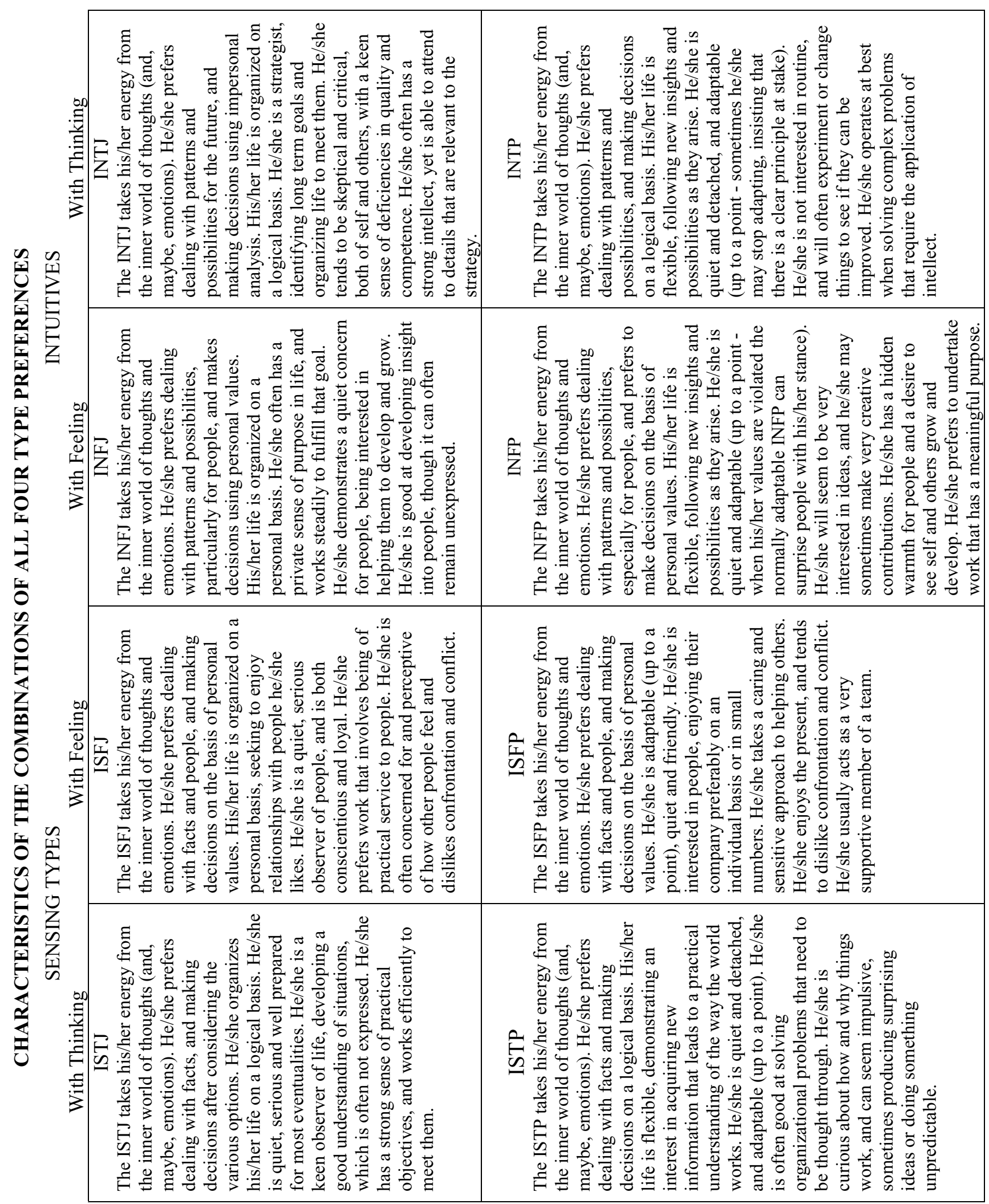




\begin{tabular}{|c|c|c|}
\hline & 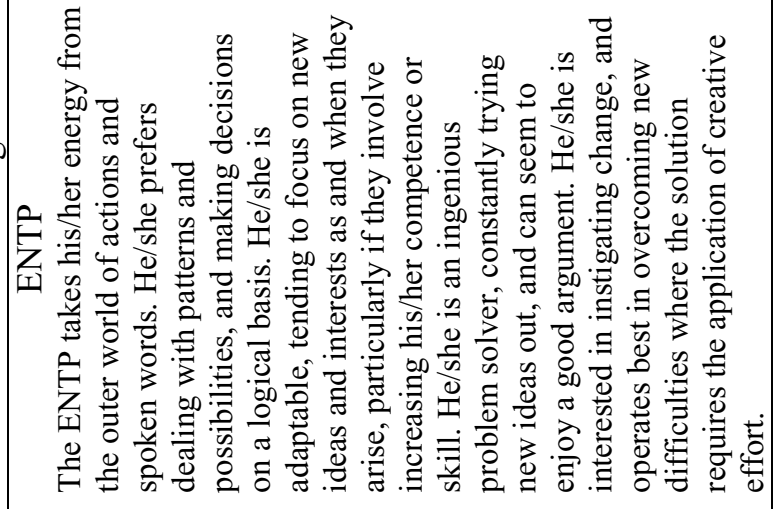 & 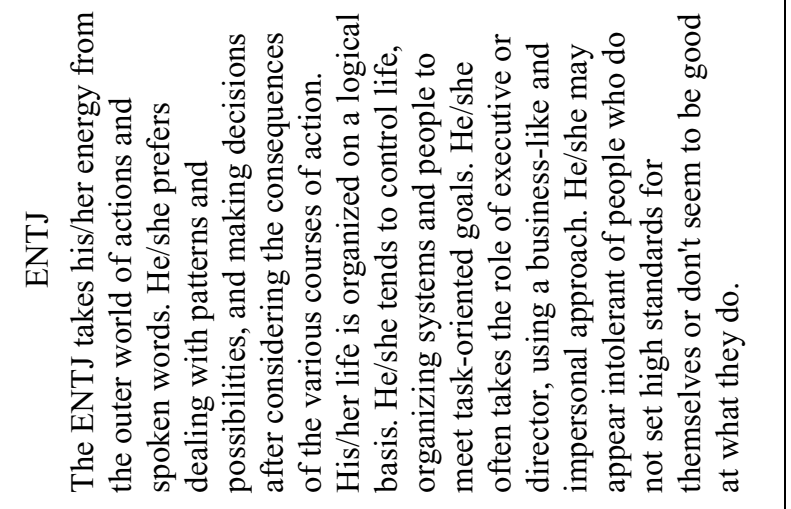 \\
\hline & 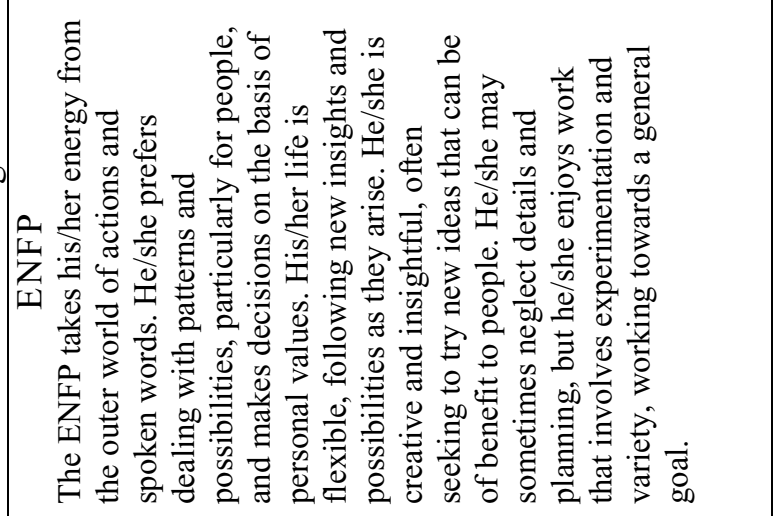 & 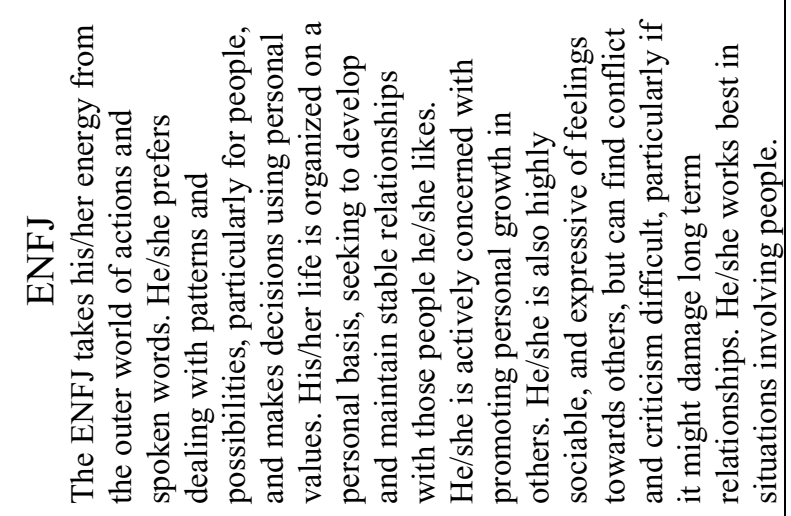 \\
\hline & 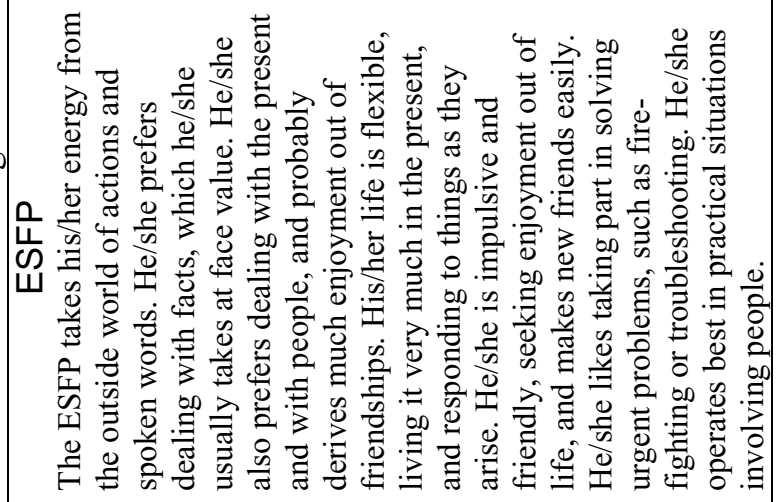 & 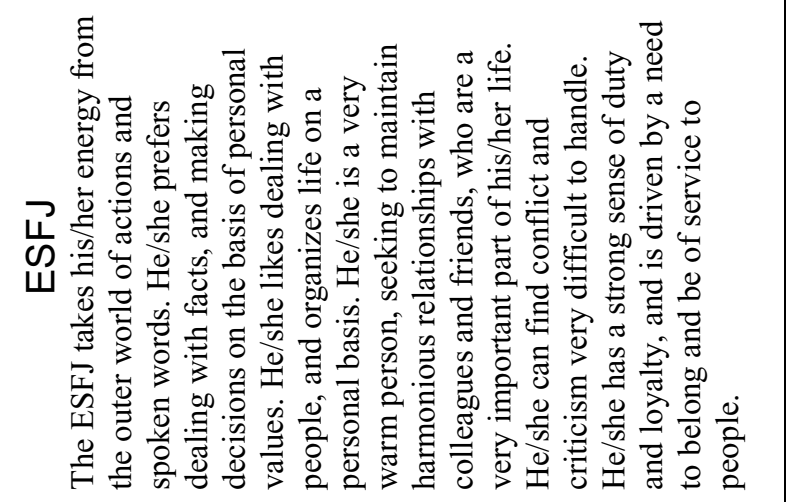 \\
\hline 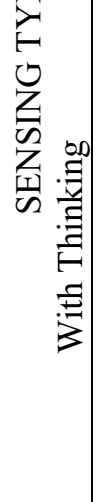 & 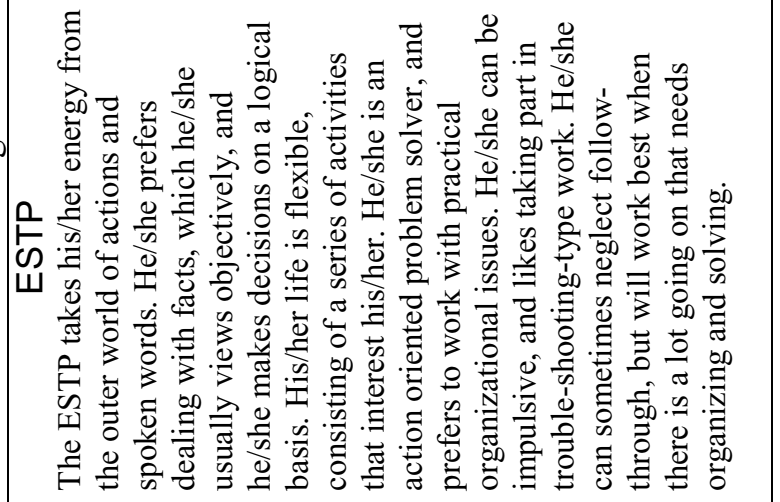 & 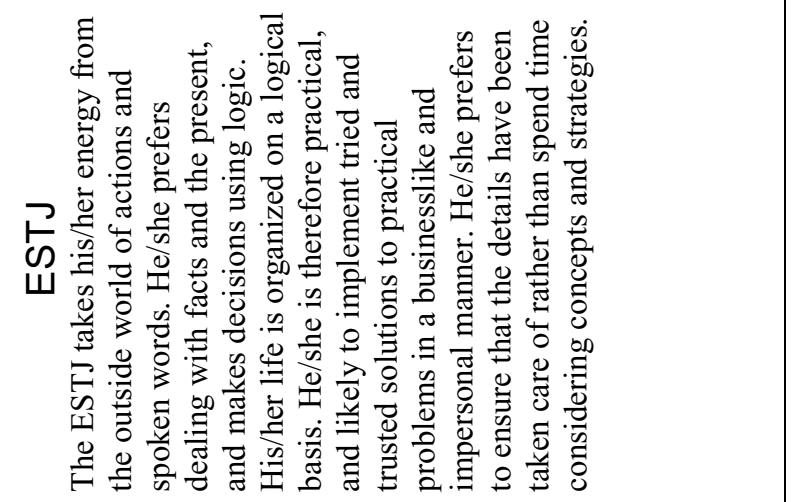 \\
\hline
\end{tabular}


